\title{
LARGE SCALE ISOLATION AND PARTIAL CHARACTERIZATION OF SOME CARBOXYPEPTIDASES FROM MALTED BARLEY.
}

\author{
by \\ LEE E. RAY* \\ Department of Chemistry - Carlsberg Laboratory \\ Gamle Carlsberg Vej 10 - DK-2500 Copenhagen, Valby \\ *Present address: Department of Biology, Texas A\&M University, College Station, Texas 77843.
}

Key-words: carboxypeptidase, barley, malt, isoelectric focusing

\begin{abstract}
The carboxypeptidase activity in the water extract of malted barley was resolved into five components; two of these (CP 1-1 and CP 2-1) were obtained in high purity and were partially characterized in regard to enzymatic and chemical properties. Both appeared homogeneous by polyacrylamide gel electrophoresis and ultracentrifugation. The MW of CP $1-1$ was 81,500 by sedimentation equilibrium and 96,000 by gel filtration; for $C P$ 2-1, the values were 85,000 and 94,000 respectively. Sedimentation coefficients, $s_{20, w}$, were 5.5 for CP $1-1$ and 5.6 for $\mathrm{CP} 2-1$. The isoelectric point was $\mathrm{pH} 5.75$ for both enzymes. Carbohydrate comprised $6.6 \%$ of $\mathrm{CP} 1-1$ and 7.6\% of CP 2-1. The carboxypeptidases hydrolyzed Z-Phe-Ala, Z-Phe-Ser, Z-Phe-Leu, Z-Glu-Tyr and ATEE, plus other substrates; the $\mathrm{pH}$ of optimal activity and $\mathrm{Km}$ values were determined for several of these. Carboxypeptidase activity was inhibited strongly by diisopropylfluorophosphate and $p$-hydroxymercuribenzoate, mildly by a number of carboxylic acids and their derivatives, and weakly by metal chelators, metal ions and urea.
\end{abstract}

\section{INTRODUCTION}

Several fungal $(8,9,13,18,19,20,21,25)$ and plant $(11,12,15,16,25)$ carboxypeptidases have been isolated and studied and these can be divided into two groups based on their inhibition by p-hydroxymercuribenzoate (pHMB) ${ }^{1}$.
One group $(8,9,13,18,19,20,21)$ is strongly inhibited by $\mathrm{pHMB}$, suggesting a critical sulfhydryl group; whereas the other group $(15,16)$ is less sensitive, or insensitive, to pHMB, but can be inhibited by $\mathrm{HgCl}_{2}$ or iodoacetate, suggesting that a free sulfhydryl group may be (Footnote ${ }^{1}$ is placed page 170 ) 
present but that it may not be involved in catalysis or that binding of substrate induces a conformational change which increases its reactivity. Others are insensitive to all sulfhydryl agents $(11,12)$ or have not been tested (25). Enzymes in both groups are inhibited by diisopropylfluorophosphate (DFP) but not by metal chelators. This pattern of inhibition is in marked contrast to that observed in mammalian carboxypeptidase $A$ which is inhibited by metal chelators but not by DFP or pHMB (24). Likewise, the relatively unreactive sulfhydryl group in these carboxypeptidases differs sharply from the highly reactive sulfhydryl in the active site of papain (2) and, in at least two cases $(9,25)$, the amino acid sequence surrounding the reactive serine is different from that in trypsin and chymotrypsin (26) or subtilisin (23). Because of these differences, it is questionable whether these carboxypeptidases use either the typical serine or sulfhydryl mechanisms; they may use some hybrid or intermediate reaction mechanism. The present project was undertaken to study the reactivity of the active seryl and sulfhydryl groups in a barley carboxypeptidase in order to determine the mechanism of catalysis.

The carboxypeptidase to be studied has been isolated on a small scale from germinated Pirkka barley and partially characterized by VISURI et al.. (29). The enzyme hydrolyzes a number of benzyloxycarbonyl-dipeptides, but not those which contain proline, has a $\mathrm{pH}$ optimum of about pH 5.2 and molecular weight of about 90,000 , and is inhibited by DFP and pHMB (29). Thus, this barley carboxypeptidase seemed suitable for this study and it was necessary only to develop a large scale purification procedure and reconfirm the basic properties of the enzyme before continuing with the detailed inhibition and mechanistic studies.

\section{MATERIALS}

Malted Emir barley was a gift from Tuborg Brewery, Copenhagen. Reagents and column materials were purchased from the sources indicated: N-acetyl-L-tyrosine ethyl ester (ATEE), Sigma Chemical Co.; benzyloxycarbonyl (Z) dipeptides, Cyclo Chemical Co.; 2(N-morpholino) ethane sulfonic acid (MES), Calbiochem Co.; CM- and DEAE-cellulose, CM23 and DE23, W. \& R. Balston Ltd.; Sephadex G-100 and G-150, Pharmacia Fine Chemicals; Ampholine carrier ampholytes, LKB-Produkter AB; others were obtained from the usual sources.

Chemicals were reagent grade or the highest purity available, except ammonium sulfate and acetone which were purum grade. Demineralized water was used for the initial large-scale extraction and deionized, distilled water was used at all other stages.

\section{METHODS}

\subsection{Enzyme assays.}

Carboxypeptidase activity was routinely assayed at $25^{\circ}$ by following the hydrolysis of benzyloxycarbonyl-L-phenylalanine-L-alanine (ZPA) at $230 \mathrm{~nm}$ with a Cary Model 118 spectrophotometer. The reaction was started by adding the enzyme solution, usually 10 to 50 $\mu \mathrm{l}$, to $1 \mathrm{ml}$ of $2 \mathrm{mM}$-ZPA in $50 \mathrm{mM}$-MES, pH 5.2 , in a $1 \mathrm{~cm}$ cuvette and following the decrease in absorbance at $230 \mathrm{~nm}$ as a function of time. In some early experiments the buffer was $50 \mathrm{~m} M-\mathrm{Na}$ acetate, $\mathrm{pH}$ 5.2. One unit was defined as the amount of enzyme necessary to release one micromol of alanine per min at $25^{\circ}$ calculated with an experimentally determined extinction coefficient of $222 \mathrm{M}^{-1} \mathrm{~cm}^{-1}$.

Esterolytic activity of the carboxypeptidase was measured at $\mathrm{pH} 7.0$ and $25^{\circ}$ by the $\mathrm{pH}$-stat technique (18) with $5 \mathrm{~m} M$-ATEE in $0.1 \mathrm{M} \mathrm{KCl}$ as substrate and $25 \mathrm{mM}$ - or $50 \mathrm{mM}-\mathrm{NaOH}$ as titrant. The reaction was started by adding $100 \mu 1$ of enzyme to $10.0 \mathrm{ml}$ of substrate in the reaction vessel.

\subsection{Protein assay.}

Protein was determined by the method of

1. The abbreviations used are: ATEE, N-acetyl-L-tyrosine ethyl ester; CM-cellulose, carboxymethyl cellulose; DEAE-cellulose, diethylaminoethyl cellulose; DFP, diisopropylfluorophosphate; EDTA; ethylenediamine tetraacetate; MES, 2-(N-morpholino) ethane sulfonic acid; OP, orthophenanthroline; pHMB, p-hydroxymercuribenzoate; SDS, sodium dodecyl sulfate; Z-, benzyloxycarbonyl; ZPA, Z-L-phenyialanine-L-alanine. 
LOWRY et al. (14) with bovine serum albumin as the standard or from the absorbance at $280 \mathrm{~nm}$ using $\mathrm{E}^{1 \%}=16.5$ as reported by VISURI et al. (29).

\subsection{Amino acid analysis.}

Samples, ca. $75 \mu \mathrm{g}$ each, were hydrolyzed with $100 \mu 16 \mathrm{~N}-\mathrm{HCl}$ for 24,48 or $72 \mathrm{hr}$ at $112^{\circ}$; the hydrolysates were analyzed by a Durrum D-500 amino acid analyzer. Half-cystine and methionine were determined as cysteic acid and methionine sulfone, respectively, after performic acid oxidation as described by HiRS (10). Tryptophan was determined spectrophotometrically by the method of GoODWIN and MORTON (6); tyrosine was confirmed by this procedure.

\subsection{Isoelectric focusing.}

Isoelectric focusing experiments were performed according to the procedure of VESTERBERG and SVENSSON (28) in a jacketed LKB ampholine column of $110 \mathrm{ml}$ capacity or in an LKB Uniphor column of about $200 \mathrm{ml}$ capacity. The $\mathrm{pH}$ gradient was formed using LKB carrier ampholines (either pH 3.5-10 or $\mathrm{pH} 4-8$ ) at a final concentration of $1 \%$; it was stabilized by a linear sucrose gradient. For the small column, the sucrose gradient was prepared with an LKB ampholine gradient mixing device and was pumped into the column at about $80 \mathrm{ml} / \mathrm{hr}$; for the large column the sucrose gradient was prepared with an LKB UItrograd mixer and was pumped into the column at about $140 \mathrm{ml} / \mathrm{hr}$. For both columns the sucrose gradient was prepared from two solutions, one containing the sample, ampholytes and sucrose (ca. $47 \% \mathrm{w} / \mathrm{v}$ ), the other containing sample and ampholytes; the electrode solutions consisted of $1 \% \mathrm{H}_{3} \mathrm{PO}_{4}$, containing ca. $50 \%(\mathrm{w} / \mathrm{v})$ sucrose, for the anode and $2 \%$ ethylenediamine for the cathode. Focusing was started at 400 volts in the smaller column and 500 volts in the larger; these values were increased to 500 volts and $800-1100$ volts, respectively, during the experiments. Cold water $\left(4^{\circ}\right)$ was circulated through the jackets of both columns during the experiments. After equilibrium was reached, the contents were pumped out from the bottom at about $40 \mathrm{ml} / \mathrm{hr}$ and collected in fractions of 1.2 or $3.1 \mathrm{ml}$. The $\mathrm{pH}, \mathrm{A}_{280}$ and carboxypeptidase activity were measured in selected fractions.

\subsection{Ultracentrifugation.}

Samples were dialyzed against $\mathrm{NaCl}-\mathrm{Na}$ acetate buffer (according to MILLER and GOLDER (4)) at pH 5.3 and an ionic strength of 0.1 . Sedimentation velocity experiments were performed at $59,780 \mathrm{rev} . / \mathrm{min}$ and sedimentation equilibrium (30) experiments were performed at 20,410 rev./min For experiments of both types, an An-D rotor was used and the temperature was $20^{\circ}$. Schlieren and Rayleigh interference patterns were photographed on Kodak spectroscopic or metallographic plates and displacements were measured with a microcomparator.

\subsection{Other methods.}

Polyacrylamide gel electrophoresis was carried out at $\mathrm{pH} 3.8,8.0$ and 9.5 in $7.5 \%$ gels prepared according to GABRIEL (5) and in $10 \%$ gels containing $0.1 \%$ sodium dodecyl sulfate (SDS) as described by WEBER and OSBORN (27). Stacking gels were not used, but the densities of the sample solutions were increased by the addition of sucrose (ca. $10 \% \mathrm{w} / \mathrm{v}$ ) or urea (ca. $8 \mathrm{M}$ ).

Carbohydrate was determined by the method of ASHWELl (3) using phenol and sulfuric acid and is reported as glucose. The absorbance at 490 $\mathrm{nm}$ was measured after $30 \mathrm{~min}$. Phosphate was estimated by the method of AMEs (1) using ascorbic acid and ammonium molybdate; the absorbance at $820 \mathrm{~nm}$ was measured after 20-30 $\mathrm{min}$. Free thiol groups were measured by means of ElLMAN's reagent (5,5' dithiobis-(2-nitrobenzoic acid)) according to HABEEB (7). The absorbance at $412 \mathrm{~nm}$ was measured after 20-30 min and the sulfhydryl content was calculated using an extinction coefficient of 13,600 $\mathrm{M}^{-1}$ $\mathrm{cm}^{-1}$ (7). All absorbance measurements were performed with a Beckman Model DU or a Cary Model 118 spectrophotometer.

\subsection{Purification procedure for carboxypeptidase.} 3.7.1 Extraction.

Malted Emir barley was suspended in distilled or demineralized water (about 51 per kg malt) and the suspension was adjusted to $\mathrm{pH} 4.9$ with 
acetic acid. The suspension was stirred vigorously $2-3 \mathrm{hr}$ and then allowed to stand overnight to permit the malt and insoluble material to settle. The clear supernatant was pumped off and concentrated by ultrafiltration with a DDS ultrafiltration apparatus fitted with membrane no. 870 (nominal cut-off MW 1000) and a recirculating pump operated at $45-50$ psi (input pressure to ultrafiltration unit). The temperature was maintained at about $10^{\circ}$ by external cooling units.

\subsubsection{Ammonium sulfate fractionation.}

The concentrated extract (pH 5.9) was adjusted to $35 \%$ saturation of ammonium sulfate and allowed to stand overnight; the precipitate was removed by centrifugation and discarded. The supernatant was adjusted to $65 \%$ saturation of ammonium sulfate, allowed to stand overnight and then centrifuged. The active, $35-65 \%$ ammonium sulfate fraction was suspended in 30 $\mathrm{m} M-\mathrm{Na}$ acetate, $\mathrm{pH} 4.0$, dialyzed against the same buffer, and the insoluble material was discarded.

\subsubsection{Acetone fractionation.}

The active solution from the previous step was

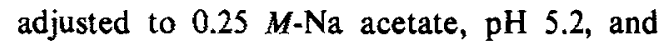
acetone $\left(-10^{\circ}\right)$ was added to give $31 \%(\mathrm{v} / \mathrm{v})$ acetone. The precipitate was removed by centrifugation and discarded. The supernatant was adjusted to $50 \%(\mathrm{v} / \mathrm{v})$ acetone, allowed to stand overnight and centrifuged. The active 31$50 \%$ acetone fraction was suspended in $25 \mathrm{mM}$ $\mathrm{Na}$ phosphate, $\mathrm{pH} 6.5$, and dialyzed against the same buffer.

\subsubsection{DEAE-cellulose chromatography.}

The active solution from the previous step was pumped through a column $(10 \times 50-60 \mathrm{~cm})$ of DEAE-cellulose equilibrated with $25 \mathrm{mM}-\mathrm{Na}$ phosphate, $\mathrm{pH} 6.5$, and the column was washed with solutions of $25 \mathrm{mM}$ and $130 \mathrm{mM}-\mathrm{Na}$ phosphate, $\mathrm{pH} 6.5$, and $100 \mathrm{mM}-\mathrm{NaCl}$ in 130 $\mathrm{m} M$-Na phosphate, $\mathrm{pH}$ 6.5. The flow rate was ca. $1.3 \mathrm{l} / \mathrm{hr}$ and the eluate was collected in fractions of about $1000 \mathrm{ml}$ each. The active carboxypeptidase peak eluted by $25 \mathrm{~m} M$ buffer was designated CP 1; that eluted by $130 \mathrm{mM}$ buffer was CP 2; and that eluted by $100 \mathrm{mM}$ $\mathrm{NaCl}$ in $130 \mathrm{~m} M$ buffer was CP 3 .

\subsubsection{CM-cellulose chromatography.}

Each of the active peaks from the preceding step was dialyzed against $30 \mathrm{~m} M-\mathrm{Na}$ acetate, $\mathrm{pH} 4.7$, and pumped through a column (10 $\times 50$ $60 \mathrm{~cm}$ ) of CM-cellulose equilibrated with the same buffer. For each sample, the column was washed with solutions of $30 \mathrm{mM}, 100 \mathrm{mM}$ and

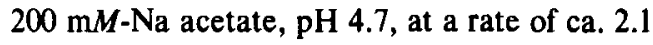
$1 / \mathrm{hr}$; fractions of about $1000 \mathrm{ml}$ each were collected. Carboxypeptidase activity was eluted by $100 \mathrm{mM}$ and $200 \mathrm{mM}$ buffer and designated as $\mathrm{CP} x-1$ and $C P \mathrm{x}-2$, respectively, where $\mathrm{x}$ denoted its manner of elution from DEAEcellulose. The active fractions from CMcellulose were concentrated by ultrafiltration and stored frozen or were adjusted to $70 \%$ saturation of ammonium sulfate and the precipitate was removed and stored at $4^{\circ}$ in 5 $\mathrm{m} M-\mathrm{Na}$ acetate, $\mathrm{pH} 5.2,60 \%$ saturated with ammonium sulfate.

\subsubsection{Gel filtration on Sephadex G-100 or G-150.}

The active fractions from the previous step were dissolved in $0.1 M$ - Na acetate, $\mathrm{pH}$ 5.2, and dialyzed against the same buffer. The samples were then pumped through a column $(2.5 \times 88$ $\mathrm{cm})$ of Sephadex G-100 or G-150 equilibrated with the same buffer and were eluted with that buffer at rates of $15-25 \mathrm{ml} / \mathrm{hr}$. The active fractions were stored frozen or were precipitated with $70 \%$ ammonium sulfate and stored at $4^{\circ} \mathrm{C}$ in $60 \%$ ammonium sulfate in $5 \mathrm{mM}$ - Na acetate, $\mathrm{pH} 5.2$.

\subsubsection{Isoelectric focusing.}

In some cases, the active fractions from gel filtration were dialyzed against distilled water, mixed with carrier ampholytes of the desired $\mathrm{pH}$ range and subjected to isoelectric focusing as described in section 3.4. The active fractions were combined, dialyzed against $20 \mathrm{~m} M-\mathrm{Na}$ acetate, pH 5.2., and stored frozen.

\section{RESULTS}

\subsection{Purification of barley carboxypeptidase.}

The purification procedure was essentially the 
Purification of carboxypeptidase from malted Emir barley.

\begin{tabular}{|c|c|c|c|c|c|}
\hline Step & $\begin{array}{l}\text { Activity, } \\
\text { unitsa }\end{array}$ & $\begin{array}{l}\text { Protein, } \\
\quad \mathrm{g}\end{array}$ & $\begin{array}{l}\text { Specific } \\
\text { activity, } \\
\text { units/mg }\end{array}$ & $\begin{array}{l}\text { Purification, } \\
\quad \text { fold }\end{array}$ & $\begin{array}{c}\text { Recovery, } \\
\%\end{array}$ \\
\hline \multicolumn{6}{|l|}{ 1. Extraction, $\mathrm{pH} 4.9$} \\
\hline $\begin{array}{l}16001 \mathrm{H} \mathrm{H}_{4} ; 8501 \text { recovered } \\
\text { B. } 327 \mathrm{~kg} \text { malt suspended in }\end{array}$ & 534,650 & 633 & 0.84 & 1 & 100 \\
\hline \multicolumn{5}{|l|}{ 2. Concentration by ultrafiltration } & 100 \\
\hline A. 147 I from Extraction A. & 374,850 & 497 & 0.75 & 0.9 & 75 \\
\hline 1601 from Extraction B. & 380.800 & 672 & 0.57 & 0.9 & 87 \\
\hline Total concentrated extract, 3071 & 755,700 & 1169 & 0.64 & $1.0^{\mathrm{b}}$ & $100^{\mathrm{b}}$ \\
\hline \multicolumn{5}{|l|}{ 4. Ammonium sulfate fractionation, } & 45 \\
\hline $\begin{array}{l}\text { 5. Acetone fractionation, } 31-50 \% \\
\text { 6. Chromatography on DE-cellulose }\end{array}$ & 191,200 & 282 & 0.68 & 1.1 & 25 \\
\hline CP 2 & 116,640 & 73 & 1.6 & 2.5 & 15 \\
\hline CP 3 & 42,600 & 38.6 & 1.1 & 1.7 & 5.6 \\
\hline \multicolumn{6}{|l|}{ 7. Chromatography on CM-cellulose } \\
\hline CP $2-1$ & 43,120 & 10.6 & 4.1 & 6.4 & 5.7 \\
\hline CP 2-2 & 8,360 & 6.8 & 1.2 & 1.9 & 1.1 \\
\hline CP 3-1 & 6,160 & 1.4 & 4.3 & 6.7 & 0.8 \\
\hline CP 3-2 & 5,010 & 1.5 & 3.3 & 5.2 & 0.7 \\
\hline \multicolumn{6}{|l|}{ 8. Gel filtration on Sephadex G150 } \\
\hline CP $1-1^{c}$ & 10,440 & 0.22 & 47.5 & - & - \\
\hline CP 2-1 & 38,800 & 2.33 & 16.6 & 25.9 & 5.1 \\
\hline \multicolumn{6}{|l|}{ 9. Isoelectric focusing } \\
\hline $\mathrm{CP} I \cdot \mathrm{I}^{\mathrm{c}}$ & 8,460 & 0.068 & 124 & - & - \\
\hline CP 2-1 & 23.300 & 0.275 & 84.7 & 132 & 3.1 \\
\hline
\end{tabular}

a. Activity was determined at $25^{\circ}$ with $2 \mathrm{mM}-\mathrm{ZPA}$ in $50 \mathrm{mM}-\mathrm{MES}$, pH 5.2, as described in section 3.1.

b. The actual purification and recovery of the combined concentrates were 0.9 -fold and $81 \%$, respectively; however the total extract was taken as the basis of comparison for the subsequent steps.

c. This material represents a number of separate, smaller extractions combined at various stages of purification; due to its diverse origin, no purification or recovery data could be calculated.

same as that used by VISURI et al. (29); except their final precipitations with ammonium sulfate and acetone were replaced by an isoelectric focusing step. The results of several trial purifications, each starting with $10-20 \mathrm{~kg}$ barley, were essentially the same as reported by VISURI $e t$ al. (29); the results of the purification from a total of $610 \mathrm{~kg}$ of malted barley are summarized in Table 1. As indicated in that Table, the malt was extracted in two portions and these extracts were concentrated before they were combined and carried through the rest of the procedure. Due to the high content of solids, both malt and flour, in the extract, it was not technically or economically efficient to use it all; thus, the recovery from this step was about $50 \%$ of the volume added originally. Of the remainder, about half was imbibed by the malt, so the total loss of solubilized enzyme in this step was estimated to be about $33 \%$. The composite recovery from concentration of the available extract was about $81 \%$, but this solution was taken as the basis for calculation of recovery and purification at subsequent steps.

Recovery of carboxypeptidase from the ammonium sulfate and acetone fractionations 


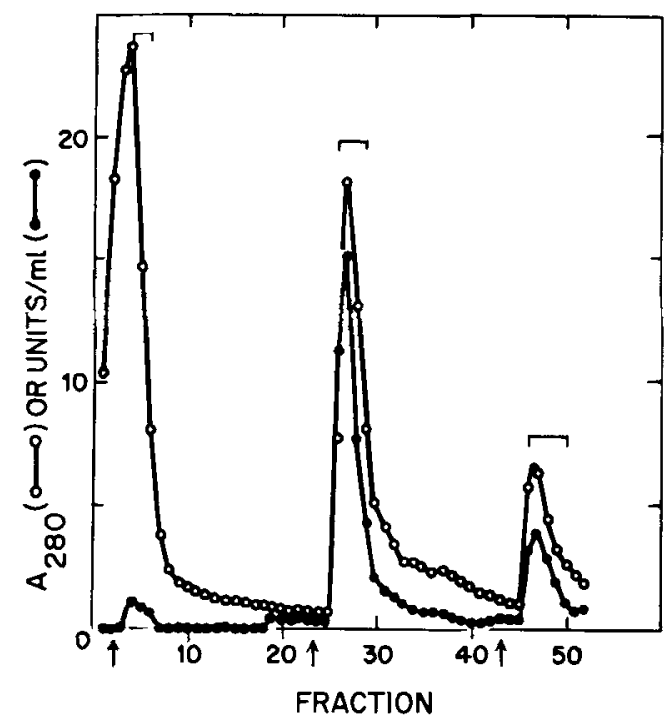

Figure 1. Chromatography of malt carboxypeptidase on DEAE- cellulose. The active ammonium sulfate fraction $(83,810$ units $)$ in $4180 \mathrm{ml} 25 \mathrm{mM}-\mathrm{Na}$ phosphate, pH 6.5, was pumped into a column $(10 \mathrm{x}$ $58 \mathrm{~cm}$ ) of DEAE-cellulose DE-23 equilibrated with the same buffer. The enzyme was eluted with $25 \mathrm{mM}$, and $130 \mathrm{~m} M$-Na-phosphate, $\mathrm{pH} 6.5$, and $100 \mathrm{mM}$ $\mathrm{NaCl}$ in $130 \mathrm{~m} M-\mathrm{Na}$ phosphate, $\mathrm{pH}$ 6.5. The arrows indicate initiation of each buffer. The first $3000 \mathrm{ml}$ of effluent were discarded and then fractions of $990 \mathrm{ml}$ were collected; the flow rate was $1275 \mathrm{ml} / \mathrm{hr}$. The brackets represent the positions of CP 1, CP 2 and CP 3 , respectively.

(Table 1; steps $4 \& 5$ ) and the degree of purification were lower than expected on the basis of the previous work. These were inefficient steps in that their total purification was less than 1.1 and the recovery was about $25 \%$. Chromatography of this material on DEAE-cellulose (Fig. 1) reproducibly gave one major and one minor peak of carboxypeptidase activity; these were eluted by $130 \mathrm{~m} M-\mathrm{Na}$ phosphate, $\mathrm{pH} 6.5$, and by $100 \mathrm{~m} M-\mathrm{NaCl}$ in the same buffer and were designated $C P 2$ and $C P 3$, respectively. In addition, some samples gave a relatively small, but variable, peak of activity which was eluted by the starting conditions of $25 \mathrm{mM}$ buffer; this was designated CP 1. (Fig. 1).

Although CP 2 appeared to correspond to the material used by VISURI et al. (29), all three peaks were chromatographed on CM-cellulose.
In all cases most of the active material was retained by the resin when applied in $30 \mathrm{~m} M-\mathrm{Na}$ acetate, $\mathrm{pH} 4.7$; about $2 \%$ of the activity was not retained under these conditions and was discarded. The variable CP 1 peak was eluted as a single peak from CM-cellulose by $100 \mathrm{mM}-\mathrm{Na}$ acetate, $\mathrm{pH} 4.7$, and was designated as CP 1-1. A portion of the characterization work to be described was carried out on this material. The major DE-cellulose peak, CP 2, was eluted as two peaks, CP 2-1 and CP 2-2, from CMcellulose by $100 \mathrm{~m} M$ and $200 \mathrm{~m} M$-Na acetate, pH 4.7, respectively (Fig. 2). The first peak, CP 2-1, which included most of the enzyme activity, appeared to correspond to the material studied by VISURI et al. (29) and was used for most of the work to be described herein. The minor DE-cellulose peak, CP 3, was also eluted as two peaks, CP 3-1 and CP 3-2, from CMcellulose by $100 \mathrm{~m} M$ and $200 \mathrm{~m} M-\mathrm{Na}$ acetate, $\mathrm{pH} 4.7$, respectively. Although the specific

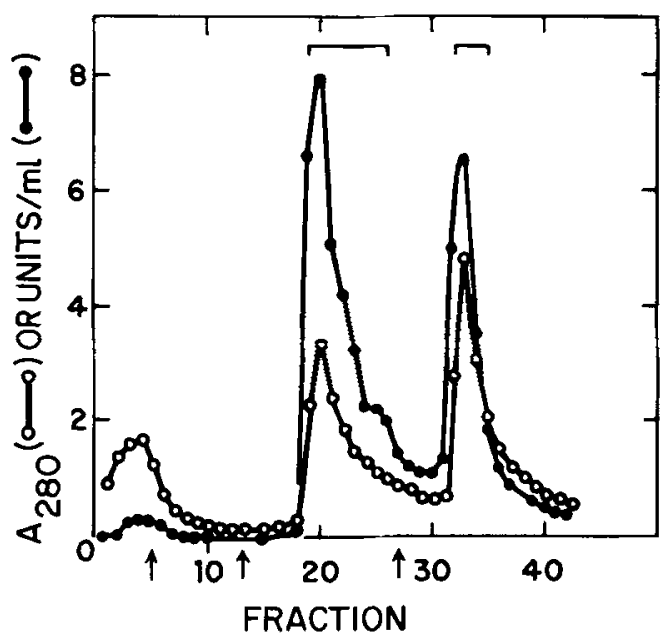

Figure 2. Chromatography of malt carboxypeptidase CP 2 on CM-cellulose. The active carboxypeptidase CP 2 pool (fractions 26-29 of Fig. 1 plus comparable ones from a duplicate column) was adjusted to $\mathrm{pH}$

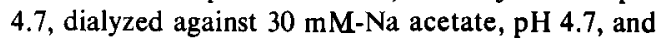
pumped into a column $(10 \times 52 \mathrm{~cm})$ of CM-cellulose CM-23 equilibrated with the same buffer; 67,050 units in $8520 \mathrm{ml}$ were applied. The enzyme was eluted with $25 \mathrm{mM}, 100 \mathrm{mM}$ and $200 \mathrm{mM}-\mathrm{Na}$ acetate, $\mathrm{pH} 4.7$; the arrows indicate initiation of each buffer. The first 4 fractions contained $2000 \mathrm{ml}$ each, subsequent ones $980 \mathrm{ml}$ each; the flow rate was $2130 \mathrm{ml} / \mathrm{hr}$. The brackets represent the positions of $\mathrm{CP} 2-1$ and $\mathrm{CP} 2-2$ respectively. 


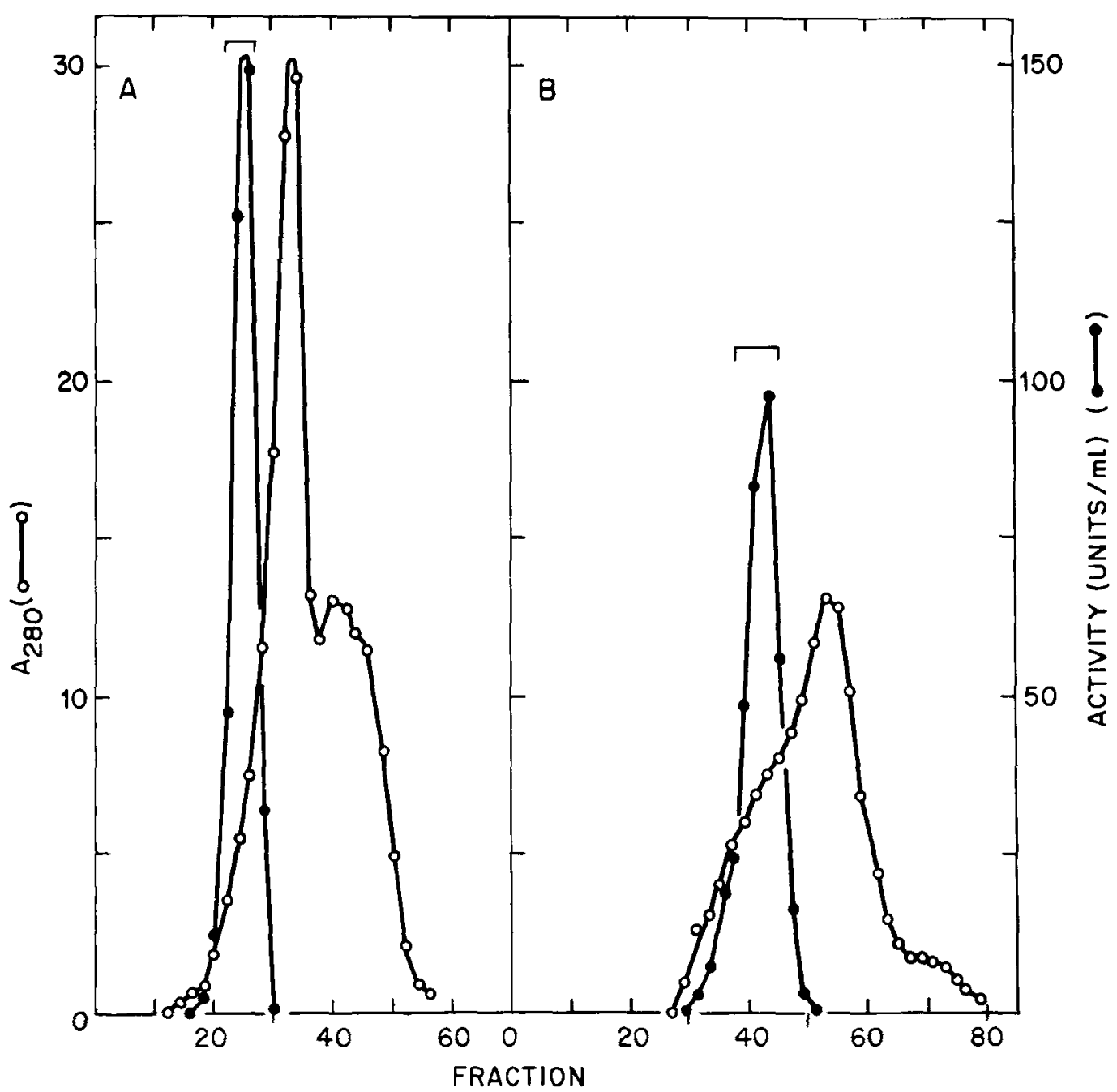

Figure 3. Chromatography of CP 1-1 and CP 2-1 on Sephadex G-150. Carboxypeptidase CP 1-1 or CP 2-1 (Fig. 2) was concentrated, equilibrated with $100 \mathrm{~m} M-\mathrm{Na}$ acetate, pH 5.2, pumped into a column $(2.5 \times 88 \mathrm{~cm})$ of Sepadex G-150 equilibrated with the same buffer, and was eluted with that buffer. A. Carboxypeptidase CP 1-1 (7550 units); the flow rate was ca. $15 \mathrm{ml} / \mathrm{hr}$, fractions were ca. $9.8 \mathrm{ml}$ each. B. Carboxypeptidase CP 2-1 (3760 units); the flow rate was ca. $25 \mathrm{ml} / \mathrm{hr}$, fractions were ca. $4.9 \mathrm{ml}$. each.

activity of these two components was comparable to that of $\mathrm{CP} 2-1$, the samples were highly pigmented and they were subsequently used only for gel filtration and sedimentation velocity experiments.

Gel filtration resulted in a single peak of activity from each of the various peaks obtained by ion-exchange chromatography; the activity was located in a sharp peak within a broad band consisting of 2 or 3 poorly resolved protein peaks (Fig. 3). With CP 1-1 and CP 2-1, this peak was lightly pigmented whereas with the other samples it was heavily pigmented. Isoelectric focusing of both CP 1-1 and CP 2-1 after gel filtration produced a single peak of activity plus two nonactive protein peaks, (Fig. 4). The activity focused at pH 5.75 and was essentially free of pigment whereas the major nonactive peak focused at $\mathrm{pH}$ 5.1-5.4 and was slightly pigmented. A relatively small, nonactive peak was present at $\mathrm{pH} 6.0-6.2$. The final specific activity of CP 2-1 was 84.7 units/mg 


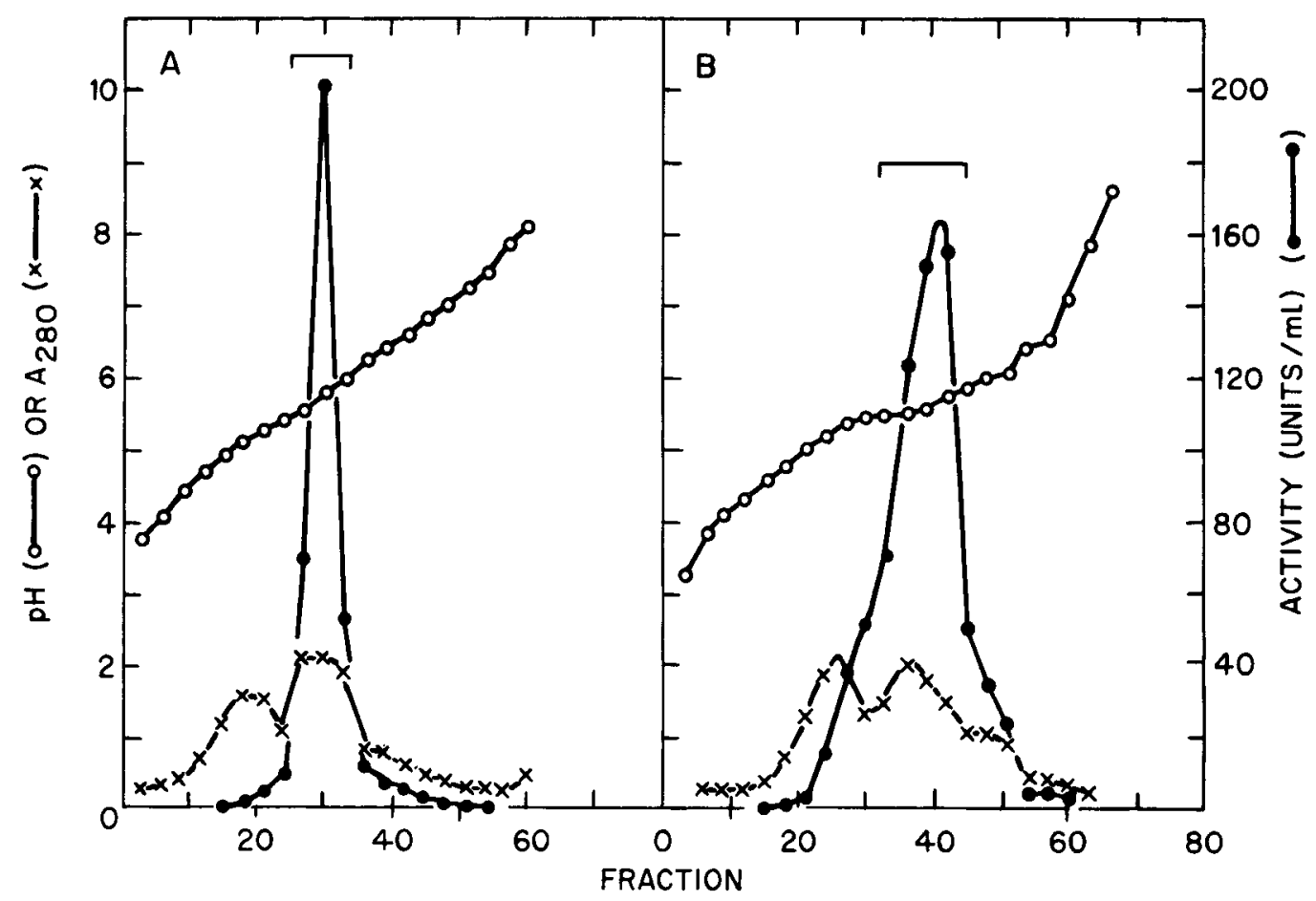

Figure 4. Isoelectric focusing of CP 1-1 and CP 2-1. Carboxypeptidase CP 1-1 or CP 2-1 was prepared as detailed in the text (Section 3.7.7.) and subjected to isoelectric focusing for 5 days; the final voltage was $1100 \mathrm{v}$. The focused solution was pumped out at $47 \mathrm{ml} / \mathrm{hr}$. A. Carboxypeptidase CP 1-1, ca. 2500 units; fractions $3.1 \mathrm{ml}$ each. B. Carboxypeptidase CP 2-1, ca. 5750 Units; fractions $3.0 \mathrm{ml}$ each.

protein, representing a purification of 132 -fold; the recovery was $3.1 \%$ (Table 1 ). The final specific activity of CP 1-1 was 124 units/mg protein (Table 1); due to the diverse origin of the material it was not possible to calculate the recovery or purification.

\subsection{Homogeneity and physical properties of the} enzyme.

The carboxypeptidase preparations appeared essentially homogeneous on the basis of electrophoretic patterns and ultracentrifugation. Gel electrophoresis of $\mathrm{CP} \mathrm{2-1}$ at $\mathrm{pH} 3.8$ and at $\mathrm{pH} 9.5$ after treating the enzyme with DFP revealed only one protein band of high mobility (Fig. 5); electrophoresis at pH 7.0 or 9.5 or in the presence of SDS revealed a diffuse zone of protein. In sedimentation velocity experiments, each enzyme sedimented as a single, symmetrical peak with a sedimentation coefficient, $\mathrm{s}_{20, \mathrm{w}}$, of 5.5 for CP 1-1 and 5.6 for CP 2-1.
Sedimentation equilibrium experiments also indicated CP 1-1 and CP 2-1 to be homogeneous since there was a linear relationship between the $\log$ of the fringe displacement and the square of the radius of rotation.

Based on the sedimentation equilibrium experiments, the molecular weight of CP 1-1 was 81,500 and that of CP 2-1 was 85,000 . Based on gel filtration through Sephadex G-150, the values were 96,000 and 94,000 , respectively.

The isoelectric point was $\mathrm{pH} 5.75$ for both $\mathrm{CP}$ 1-1 and CP 2-1.

Preliminary amino acid analyses based on duplicate $24 \mathrm{hr}$ hydrolysates are shown in Table II. The number of residues (30) of tyrosine for CP 2-1 determined by amino acid analysis was significantly lower than that (43 residues) determined spectrophotometrically, whereas for $\mathrm{CP} 1-1$ the two procedures gave similar values (Table II). The value obtained spectrophotometrically was considered more 
reliable in the case of CP 2-1. Based on the extinction coefficients reported for these residues by GOODWIN and MORTON (6), the calculated $E_{280}^{1 \%}$ nm was 14.5 for CP 1-1, assuming 42 tyrosines and 15 tryptophans; the value was 15.1 for CP 2-1, assuming 43 tyrosines and 16 tryptophans. These values were 8-12\% lower than that (16.5) reported by VISURI et al. (29). In addition, CP $1-1$ contained $6.6 \%$ carbohydrate and $\mathrm{CP} 2-1$ contained $7.6 \%$ carbohydrate; neither enzyme contained phosphate.

\subsection{Enzymatic properties of malt carboxypep- tidase.}

The enzymes hydrolyzed a number of Z-dipeptides, and, as shown in Table III, both CP 1-1 and CP 2-1 were optimally active under moderately acidic conditions. Hydrolysis of $\mathrm{ZPA}$, the routine substrate, was most rapid at pH 4.6-4.9 (Fig. 6; Table III); CP 2-1 and CP 1-1 had approximately the same affinity for this substrate as shown by the $\mathrm{Km}$ values of $2.0 \mathrm{mM}$ and $2.1 \mathrm{mM}$, respectively (Fig. 7; Table III). With Z-phe-ser both the $\mathrm{pH}$ optima and affinities were slightly lower, viz., $\mathrm{pH}$ 4.4-4.6 and $\mathrm{Km}$ values of $4.8 \mathrm{~m} M$ and $3.7 \mathrm{mM}$ for $\mathrm{CP}$ 11 and CP 2-1, respectively (Table III). The pH optima for Z-phe-leu were still lower (pH 4.2 or less) whereas the affinities were higher, i.c. $\mathrm{Km}$ values of $0.74 \mathrm{mM}$ for CP $1-1$ and $0.81 \mathrm{mM}$ for CP 2-1. Of the substrates tested, Z-glu-tyr had the lowest $\mathrm{pH}$ optima, i.e. pH 3.4-3.8; this could be related to protonation of the $\gamma$-carboxyl group of the substrate. In nearly all cases, the

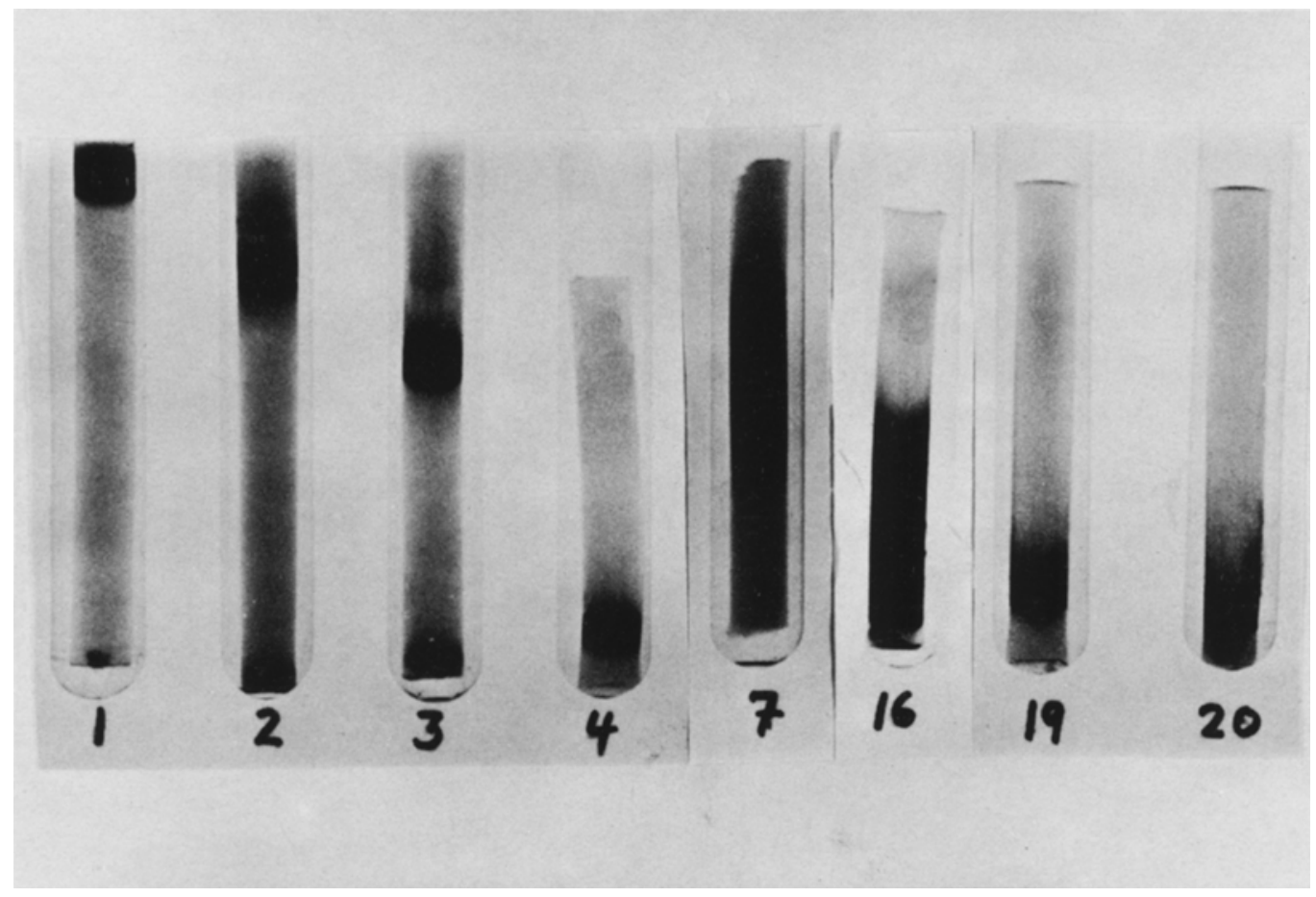

Figure 5. Electrophoresis of purified carboxypeptidase CP 2-1 on 7.5\% polyacrylamide gels. All gels were fixed in $12.5 \%$ TCA, stained with $0.05 \%$ Coomassie blue and destained in $12.5 \%$ TCA. Gels 1-3. Cationic (pH 3.8) electrophoresis of $17 \mu \mathrm{g}$ enzyme was carried out at $2 \mathrm{~mA} / \mathrm{gel}$; gels were removed after 40, 80 and $120 \mathrm{~min}$, respectively. Gel 4. Electrophoresis of $50 \mu \mathrm{g} \mathrm{CP} 2-1$ was carried out at $2.8 \mathrm{~mA} / \mathrm{gel}$ for $135 \mathrm{~min}$. Gel 7 . Enzyme (50 $\mu \mathrm{g})$ was incubated with $1 \%$ each SDS and 2-mercaptoethanol in $10 \mathrm{mM}-\mathrm{Na}$ phosphate, pH 7.0, for $16-17 \mathrm{hr}$ at $23^{\circ}$. Electrophoresis was carried out at $8 \mathrm{~mA} / \mathrm{gel}$ for $195 \mathrm{~min}$ in $10 \%$ gels containing $0.1 \%$ each SDS and 2 mercaptoethanol. Gel 16. Anionic ( $\mathrm{pH} \mathrm{8.0)} \mathrm{electrophoresis} \mathrm{of} 33 \mu \mathrm{g}$ CP 2-1 was carried out at $2 \mathrm{~mA} / \mathrm{gel}$ for 120 min. Gels 19-20. Enzyme was incubated with $30 \mathrm{mM}$-DFP at $23^{\circ}$ for $2 \mathrm{hr}$. Electrophoresis of $25 \mu \mathrm{g}$ and $33 \mu \mathrm{g}$. respectively, was carried out at pH 9.0 and $2 \mathrm{~mA} / \mathrm{gel}$ for ca. $90 \mathrm{~min}$. 
Amino acid analysis of malt carboxypeptidase CP 1-1 and CP 2-1.

\begin{tabular}{|c|c|c|}
\hline \multirow{2}{*}{ Residue } & \multicolumn{2}{|c|}{ Residues per $10^{3} \mathrm{~g}$ protein ${ }^{\mathrm{a}}$} \\
\hline & $\mathrm{CP} 1-1$ & CP 2-1 \\
\hline Aspartic acid & 103 & 106 \\
\hline Threonine & 50 & 52 \\
\hline Serine & 68 & 74 \\
\hline Glutamic acid & 74 & 89 \\
\hline Proline & 60 & 56 \\
\hline Glycine & 101 & 103 \\
\hline Alanine & 89 & 92 \\
\hline Half-cystineb & 19 & 24 \\
\hline Valine & 67 & 74 \\
\hline Methionine $e^{b}$ & 16 & 12 \\
\hline Isoleucine & 38 & 40 \\
\hline Leucine & 73 & 78 \\
\hline Tyrosine & $44 ; 40^{c}$ & $30 ; 43^{c}$ \\
\hline Phenylalanine & 44 & 49 \\
\hline Histidine & 22 & 18 \\
\hline Lysine & 36 & 37 \\
\hline Arginine & 32 & 32 \\
\hline Tryptophanc & 15 & 16 \\
\hline
\end{tabular}

a. Values are based on duplicate analyses after hydrolysis for $24 \mathrm{hr}$ in $6 \mathrm{~N}-\mathrm{HCl}$ in vacuo at $112^{\circ}$ and are reported as the nearest integer per $100,000 \mathrm{~g}$ protein.

b. Half-cystine and methionine were determined as cysteic acid and methionine sulfone, respectively, after performic acid oxidation according to Hirs (20).

c. Tyrosine (the second values) and tryptophan were determined spectrophotometrically by the method of Goodwin and Morton (21).

pH optimum for CP 1-1 closely approximated or overlapped that for CP 2-1 (Fig. 6; Table III). Furthermore, for CP 1-1 and for CP 2-1, the $\mathrm{Km}$ values for $\mathrm{Z}$-phe-ala and $\mathrm{Z}$-phe-leu were very close (Table III), which suggested that $C P$ 1-1 and CP 2-1 could be very closely related isoenzymes or perhaps the same enzyme which had undergone partial deamidation (of CP 2-1 to give $C P(-1)$ and thus change its behavior during ion-exchange chromatography.

Carboxypeptidase CP 2-1 also possessed esterolytic activity in that it was capable of hydrolyzing ATEE. Maximal activity occurred at $\mathrm{pH}$ 6.6-7.0. Finally, malt carboxypeptidase CP 2-1 was active against the oxidized B chain of insulin. With this substrate, at enzyme to substrate ratios of $1: 220$ to $1: 2000$, alanine was released in yields of $70-90 \%$. Lysine was not released, which suggested that carboxypeptidase CP 2-1 will not hydrolyze a bond involving proline, the next amino acid in the sequence.

\subsection{Effect of inhibitors on malt carboxypeptidase.} Malt carboxypeptidase was inhibited by a variety of substances, including carboxylic acids, sulfhydryl reagents and seryl reagents, but was much less sensitive to metal chelators, metal ions and denaturants (Table IV). The effects of acetate and citrate were similar, i.e., about $50 \%$ inhibition at $50 \mathrm{mM}$, but much less severe than those of succinate, $78 \%$ inhibition at $1 \mathrm{mM}$, or nitrobenzylsuccinate, $55-61 \%$ inhibition at 0.1 $\mathrm{mM}$. p-HMB caused slight but significiant inhibition, $14 \%$ at $0.1 \mathrm{mM}$. Treatment with DFP for $3 \mathrm{hr}$ caused a high initial loss of activity, 70\% at $0.33 \mathrm{mM}$ (12-fold molar excess); after prolonged incubation ( 6 days at $4^{\circ}$ ) inhibition had increased to $94 \%$. In the presence of 3.3 mM-DFP (120-fold molar excess) inhibition was $96 \%$ and $99 \%$, respectively. Treatment with 1.2 $\mathrm{m} M$ chelators (EDTA; OP) or metal ions $\left(\mathrm{Ca}^{++} ; \mathrm{Mg}^{++}\right)$caused only slight inhibition (0$12 \%$ ) of the carboxypeptidase, Table IV. Due to its high optical density, these concentrations of 
Optimal $\mathrm{pH}$ and $\mathrm{K}_{\mathrm{m}}$ values for hydrolysis of various $\mathrm{Z}$-dipeptides by purified malt carboxypeptidase.

\begin{tabular}{l|l|c|lc}
\hline \multicolumn{2}{c|}{ CP 1-1 } & \multicolumn{2}{c}{ CP 2-1 } \\
\hline Substrate & Optimum pH & $\mathrm{K}_{\mathrm{m}}, \mathrm{mM}^{\mathrm{b}}$ & Optimum $\mathrm{pH}^{\mathrm{a}}$ & $\mathrm{K}_{\mathrm{m}}, \mathrm{mM}^{\mathrm{b}}$ \\
Z-phe-ala & $4.7-4.9$ & 2.1 & $4.6-4.9$ & 2.0 \\
Z-phe-ser & $4.4-4.6$ & 4.8 & $4.4-4.5$ & 3.7 \\
Z-phe-leu & $\leqq 4.2$ & 0.74 & $\leqq 4.3$ & 0.81 \\
Z-glu-tyr & $3.4-3.7$ & - & $3.6-3.8$ & - \\
\hline
\end{tabular}

a Assays were performed with $2 \mathrm{mM}$ substrate in $50 \mathrm{mM}-\mathrm{MES}$ containing $50 \mathrm{mM}-\mathrm{NaCl}$ and $10 \mu \mathrm{l}$ of purified carboxypeptidase diluted as necessary with the same buffer.

b Assays were performed with the substrate in $50 \mathrm{mM}-\mathrm{MES}$, $\mathrm{pH} 5.25$, and $10 \mu \mathrm{l}$ of purified carboxypeptidase diluted as necessary. Values of $\mathrm{K}_{\mathrm{m}}$ were determined from Lineweaver-Burk plots using initial velocities.

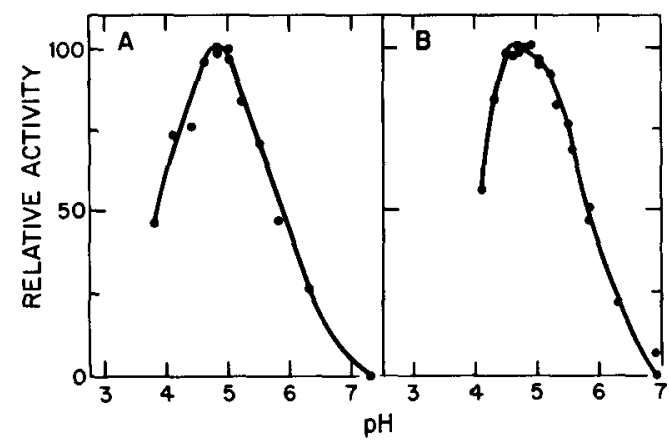

Figure 6. Effect of $\mathrm{pH}$ on the hydrolysis af Z-phe-ala by malt carboxypeptidase. Activity was measured against $2 \mathrm{mM}$-ZPA in $50 \mathrm{~m} M-\mathrm{NaCl}$ and $50 \mathrm{mM}$-MES at the indicated $\mathrm{pH}$ values with $10 \mu \mathrm{l}$ of purified carboxypeptidase CP 1-1 (A) or CP 2-1 (B) diluted as necessary. Maximum activity $(100 \%)$ was 130 units $/ \mathrm{ml}$ for CP 1-1 and 52 units/ml for CP 2-1.

OP could not be used in the assay. Similarly, the enzyme was virtually insensitive to $6.4 M$-urea when assayed with concomitant dilution of the denaturant to $26 \mathrm{mM}$.

\section{DISCUSSION}

Five carboxypeptidases active against ZPA have been separated from a water extract of malted barley by a combination of anionic and cationic exchange chromatography plus other purification steps; this substantiates the suggestions of VISURI et al. (29) and MOELLER et al. (17) that malt contains more than one such enzyme. Recovery of the purified enzymes ranged from less than $1 \%$ to $3.1 \%$ and represented less than $300 \mathrm{mg}$ of essentially homogeneous material (CP 2-1) from $610 \mathrm{~kg}$ malt. In view of the relative yields obtained in this work and that $(50 \mathrm{mg}$ from $8 \mathrm{~kg}$ malt) obtained by VISURI et al. (29), it appears that small amounts of malt are more efficient for purification of these enzymes. This may be related to degradation of the carboxypeptidases by proteolytic enzymes in the extract or to the greater time involved in processing the larger quantities. It could also be due to differences in the malting procedure or to the different genus of barley used in this work. For example, HAYASHI et al. reported the contamination of

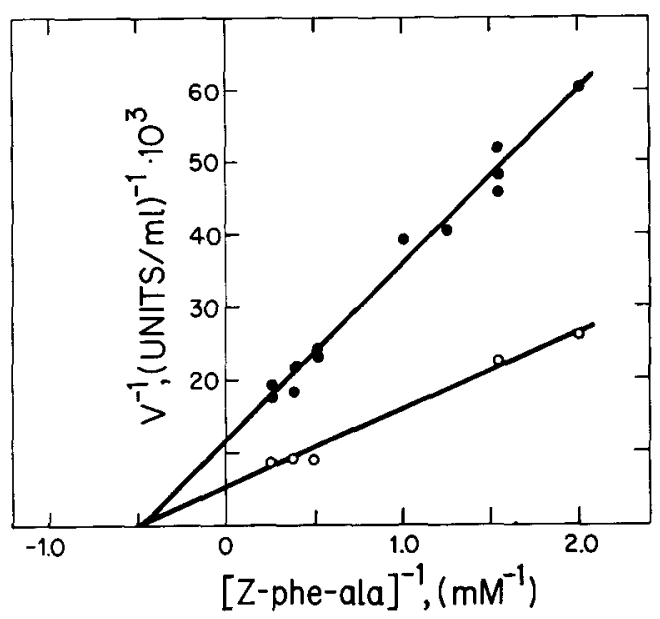

Figure 7. Double reciprocal plot of initial velocity of hydrolysis versus substrate concentration. Carboxy-

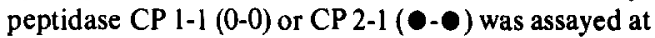
$25^{\circ}$ in $50 \mathrm{mM}$ MES, pH 5.25 , containing $0.5 \mathrm{mM}$ to 4.0 mM ZPA. 
Effect of various reagents on the activity of malt carboxypeptidase CP 2-1".

\begin{tabular}{|c|c|c|c|}
\hline \multirow[t]{2}{*}{ Regent } & \multicolumn{2}{|c|}{ Concentration, $\mathrm{mM}$} & \multirow[t]{2}{*}{ Inhibition, \% } \\
\hline & Preincubation & Assay & \\
\hline Acetate & 25 & 25 & 37 \\
\hline Acetate & 50 & 50 & 45 \\
\hline Citrate & 25 & 25 & 50 \\
\hline Citrate & 50 & 50 & $55-60$ \\
\hline Succinate $^{b}$ & 0 & 1 & 78 \\
\hline Nitrobenzylsuccinateb & 0 & 0.1 & $55-61$ \\
\hline Nitrobenzylsuccinate & 0 & 0.5 & $81-92$ \\
\hline $\mathrm{p}$-Hydroxymercuribenzoatec & 0.1 & 0.001 & 14 \\
\hline Diisopropylfluorophosphate & 0.33 & 0.008 & $70 ; 94^{d}$ \\
\hline Diisopropylfluorophosphate & 3.3 & 0.08 & $96 ; 99 \mathrm{~d}$ \\
\hline EDTA $^{e}$ & 1.2 & 1.2 & 4 \\
\hline Orthophenanthroline & 1.2 & 0.012 & 8 \\
\hline $\mathrm{Ca}++\mathrm{e}$ & 1.2 & 1.2 & 12 \\
\hline $\mathrm{Mg}^{++\mathrm{e}}$ & 1.2 & 1.2 & 0 \\
\hline Urea & 6400 & 26 & 4 \\
\hline
\end{tabular}

a. Except as noted, carboxypeptidase $\mathrm{CP} 2-1$ was incubated at $22^{\circ}$ for $1-3 \mathrm{hr}$ with each reagent at the concentration indicated and assayed with $2 \mathrm{mM}-\mathrm{ZPA}$ in $50 \mathrm{mM}-\mathrm{MES}, \mathrm{pH} 5.2$, containing the indicated concentration of inhibitor.

b. Both carboxypeptidase CP 1-1 and 2-1 were assayed without preincubation in the inhibitor.

c. Assayed at pH 5.6.

d. The sample was reassayed after 6 days at $4^{\circ}$.

e. Carboxypeptidase CP 1-1 was used; assayed with $1.78 \mathrm{mM}-\mathrm{ZPA}$ as described in a.

f. Carboxypeptidase CP 1-1 was used.

carboxypeptidase $\mathrm{Y}$ by proteinase $\mathrm{A}$ to be lower in Fleishmann's yeast than in Oriental yeast (8).

Because of the small yield and heterogeneity of three of the species, complete characterization and comparison of these was impossible. However, certain studies were possible using the other two enzymes, CP 1-1 and CP 2-1. The molecular weights, isoelectric points, sedimentation coefficients and certain kinetic parameters of these two species were very similar; this suggested these enzymes were closely related isoenzymes or perhaps that $\mathrm{CP}$ 1-1 was a deamidated form of CP 2-1. The latter possibility was supported by the fact that CP 1-1 was retained on DEAE-cellulose under conditions where CP 2-1 was not. Although not reported here, some preliminary data (e.g. sedimentation coefficients, gel filtration) on the other three enzymes suggested they also were probably isoenzymes closely related to CP 1-1 and CP 2-1.
The enzymes characterized were similar to various other plant and fungal carboxypeptidases in regard to $\mathrm{pH}$ optima, inhibition by DFP and $\mathrm{pHMB}$ and insensitivity to metal chelators and metal ions. Their substrate specificity was more limited in that they did not release the carboxy terminal amino acid when proline was penultimate. This agreed with the results of VISURI et al. (29) with N-blocked di- and polypeptides. In contrast, the carboxypeptidases from yeast (8), tomato (16), and watermelon (15) and penicillocarboxypeptidase-S (13) all hydrolyzed amino blocked dipeptides containing proline and released proline and adjacent amino acids from polypeptide chains, e.g., insulin B chain.

The degree of inhibition of CP 2-1 caused by pHMB and EDTA (Table IV) closely approximated that reported by VISURI et al. (29) whereas inhibition by DFP (Table IV) was somewhat less than reported by that group. Inhibition due to pHMB was much lower than it 
was in penicillocarboxypeptidase-S which was inhibited completely at $10^{-4}$ or $10^{-5} \mathrm{M}$ - pHMB (13), was similar to that in the acid carboxypeptidases of $A$. oryzae, ca. $70 \%$ inhibition at 1 $\mathrm{m} M$-pHMB, but was more extensive than in the enzymes from tomato and watermelon, which were inhibited $0-8 \%$ at $0.3 \mathrm{mM}$ - pHMB $(15,16)$. The relatively low inhibition of CP 2-1 due to treatment with pHMB suggested that the critical -SH group may be sterically hindered or otherwise unusual, as reported for carboxypeptidase $Y(3)$, which reacted with pHMB but not iodoacetate, and watermelon carboxypeptidase (15), which was inhibited by $\mathrm{HgCl}_{2}$ but not pHMB. The ability of CP 2-1 to hydrolyze ATEE supported the suggestion of MATOBA and DoI (15) that esterolytic activity may be common to all plant carboxypeptidases.

\section{ACKNOWLEDGEMENTS}

The author's most sincere gratitude is extended to Professor MARtin OtTesen for making this study possible and for continued encouragement, advice and assistance during the project. Sincere thanks are also extended to Dr. JACK JOHANSEN for helpful discussions and other assistance. Thanks are due to Mrs. LILliaN ABILDGAARD for assistance with many of the experiments, to Mr. ARNE JOHANSEN and Dr. TORBEN PEDERSEN for help with the ultracentrifugation, to Mrs. BODIL CORNELIUSSEN for performing the amino acid analyses and to $\mathrm{Mr}$. Oluf Jensen and Mr. Palle Nielsen, both of Tuborg Brewery, for assistance in the initial phases of the large scale extraction. Warm thanks are also due to many other members of the staff of the Carlsberg Laboratory who helped in a variety of ways and who made my stay so memorable and rewarding. Finally, the financial support of the Carlsberg Brewery is gratefully acknowledged.

\section{REFERENCES}

1. Ames, Bruce N: Assay of inorganic phosphate, total phosphate and phosphatases. Methods Enzymol. 8, 115-118 (1966)

2. Arnon, Ruth: Papain. Methods Enzymol. 19, 226-244 (1970)
3. AsHwELl, G.: New colorimetric methods of sugar analysis. Method Enzymol. 8, 85-95 (1966)

4. Dawson R. M. C., Elliot, W. H. \& Jones, Kenneth: Data for biochemical Research, 2. edition, p. 500. Oxford Univ. Press. New York (1969)

5. Gabriel, Othmar: Analytical disc gel electrophoresis. Methods Enzymol. 22, 565-578 (1971)

6. Goodwin, T. W. \& Morton, R. A.: The spectrophotometric determination of tyrosine and tryptophan in proteins. Biochem. J. 40, 628632 (1946)

7. HABEeb, A.F.S.A. : Reaction of protein sulfhydryl groups with Ellman's reagent. Methods Enzymol. 25, 437-464 (1972)

8. Hayashi, Rikimaru, Moore, Stanford \& Stein, WILlIAM H.: Carboxypeptidase from yeast. Large scale preparation and the application to $\mathrm{COOH}$ terminal analysis of peptides and proteins. J. Biol. Chem. 248, 2296-2302 (1973)

9. Hayashi, Rikimaru, Moore, Stanford \& Stein, WILliam H.: Serine at the active center of yeast carboxypeptidase. J. Biol. Chem. 248, 8366-8369 (1973)

10. Hirs, C. H. W.: Determination of cystine as cysteic acid. Methods Enzymol. 11, 59-62 (1967)

11. Ihle, James $N$. \& Dure, LeoN S.: The developmental biochemistry of cottonseed embryogenesis and germination. I. Purification and properties of a carboxypeptidase from germinating cotyledons. J. Biol. Chem. 247, 50345040 (1972)

12. IhLE, JAMES N. \& DURE, LeON S.: The developmental biochemistry of cottonseed embryogenesis and germination. II. Catalytic properties of cotton carboxypeptidase. J. Biol. Chem. 247, 5041-5047 (1972)

13. Jones, S. R. \& Hofman, T.: Penicillocarboxypeptidase-S, a nonspecific exopeptidase. Can. J. Biochem. 50, 1297-1310 (1972)

14. Lowry, O. H., Rosebrough, N- J., FARR A. L. \& RANDALL, R. J.: Protein measurement with the Folin phenol reagent. J. Biol. Chem. 193, 265-275 (1951)

15. Matoba, Teruyoshi \& Doi, Etsushiro: Purification and characterization of carboxypeptidases from the sarcocarp of watermelon. Agr. Biol. Chem. 38, 1891-1899 (1974)

16. Matoba, Truyoshi \& Dol, Etsushiro: Carboxypeptidase activity of tomato fruit during the ripening process and some enzymatic properties. Agr. Biol. Chem. 38, 1901-1905 (1974)

17. Moeller, Mary, Robbins, George S., Burger, Warren C., \& Pretice, Neville: A carboxypeptidase from germinated barley and its action on casein. J. Agr. Food Chem. 18, 886-890 (1970)

18. Nakadai, Tadanobu, Nasuno, Selichi \& OGUCHI, NobuYoshI: Purification and properties of acid carboxypeptidase I from Aspergillus oryzae. Agr. Biol. Chem. 36, 1343-1352 (1972) 
19. Nakadal, Tadanobu, Nasuno, Sellchi \& Iguchl NobuYoshi: Purification and properties of acid carboxypeptidase II from Aspergillus oryzae. Agr. Biol. Chem 36, 1473-1480 (1972)

20. Nakadal, Tadanobu, Nasuno, Seitchi \& Iguchi Nobuyoshi: Purification and properties of acid carboxypeptidase III from Aspergillus oryzae. Agr. Biol. Chem. 36, 1481-1488 (1972)

21. Nakadal, Tadanobu, Nasuno, Selichi \& Iguchi, NoBUYOSHI: Purification and properties of acid carboxypeptidase IV from Aspergillus oryzae. Agr. Biol. Chem. 37, 1237-1251 (1973)

22. Ottesen, M. \& SPector, A.: A comparison of two proteinases from Bacillus subtilis. Compt. Rend.Trav.Lab. Carlsberg 32, 63-74 (1960)

23. Ottesen, M. \& Svendsen, Ia: The subtilisins Methods Enzymol. 19, 199-215(1970)

24. Petra, Philip H.: Bovine procarboxypeptidase and carboxypeptidase A. Methods Enzymol. 19, 460-503 (1970)

25. Shaw, D. C. \& Well, J. R. E.: Radiochemical determination of a unique sequence around the reactive serine residue of a diisopropylphosphorofluoridate-sensitive plant carboxypeptidase and yeast peptides. Biochem. J. 128, 229-235 (1972)

26. WALSH, K. A.: Trypsinogens and trypsins of various species. Methods Enzymol. 19, 41-63 (1970)

27. WEBER, KLAUS \& OSBORN, MARY: The reliability of molecular weight determinations by sodium dodecyl sulfate-polyacrylamide gel electrophoresis. J. Biol. Chem. 244, 4406-4412 (1969)

28. Vesterberg, Olof \& Svensson, Harry: Isoelectric fractionation, analysis, and characterization of ampholytes in natural pH gradients. Acta Chem. Scand. 20, 820-834 (1966)

29. Visuri, K., Mikola, J. \& Enari, T. M.: Isolation and partial characterization of a carboxypeptidase from barley. Eur. J. Biochem. 7, 193-199 (1969)

30. YPhantIs, D. A.: Equilibrium ultracentrifugation of dilute solutions. Biochemistry 3, 297-317 (1964) 